\title{
Keynote Address by Nico Schrijver
}

\author{
President of the Institut de Droit international and Professor of Public \\ International Law, Leiden University
}

Mr. Chair, I greatly appreciate your invitation to participate in this debate and I thank you for the welcome that you have kindly extended to me. As President of the Institut de Droit international and professor of international law at Leiden University, it is an honour for me to have been invited by the International Law Commission to give the keynote address during the solemn part of the celebrations of seventy years of the International Law Commission. This meeting provides a welcome opportunity to reflect upon the role of the Commission and its members and the important work that you have been pursuing for the promotion of the progressive development of international law and its codification.

The theme for this celebration, "Drawing a balance for the future", is therefore very appropriate. As the afternoon programme will elaborate on the future challenges, I shall focus this morning on the progressive development of international law and its codification from a historical perspective up until today. I shall do this by making a comparison between the contributions made by the International Law Commission and the Institut de Droit international, two of the main institutions that have been working on these matters for many years.

As the Institut is almost 75 years older than the International Law Commission and stretches into three centuries, kindly allow me first to discuss our efforts for the progressive development of international law and its codification in the period before the creation of the International Law Commission. Subsequently, I will discuss some similarities and differences between the two institutions, followed by various examples where both institutions have contributed to the progressive development of international law. ${ }^{1}$ s shall finish by giving reflections for the future, thus bridging you to the afternoon session on this.

* The author gratefully acknowledges the very valuable research assistance he received from Iris van der Heijden (LLM) of the Institut de Droit international (IDI) in preparing this contribution.

1 The references to the works of the International Law Commission and the Institut de Droit international that follow below can all be found on their respective websites: $<$ http://legal. un.org/ilc/> and <http://www.idi-iil.org/>. 
The story of the Institut starts in 1873, a few years after the Franco-German War when it was realized that war is a nearly unavoidable element of the human condition. Nevertheless, the hope was expressed to succeed in making wars an exception, limiting them in number and diminishing their horrors by means of progressive development of international law. ${ }^{2}$

One of the founders of the Institut, Mr. Rolin-Jaequemyns, wrote an article in 1873 in which he acknowledged the progress made by diplomatic action and individual scientific efforts to progressively develop the law of nations (jus gentium), but he considered it to be insufficient. He identified as one of the main obstacles to diplomacy the apparent conflicts between political interests of a particular people and the general common interests of the nations together, especially in the absence of a sufficiently powerful authority. To overcome the insufficiency of diplomatic action and individual scientific efforts, he proposed collective scientific action. ${ }^{3}$ Similar thoughts were expressed by other eminent lawyers, which led in 1873 to the establishment of the Institut ${ }^{4}$ as well as the International Law Association, as non-political private associations for the promotion of progress of international law.

Indeed, since its inception the Institut has prepared several codes and proposals that facilitated the work of various diplomatic conferences. To mention some early examples, the draft regulations for international arbitral procedures adopted by the Institut in $1875^{5}$ and its Oxford Manual on the laws of war on land adopted in $1880^{6}$ served as a source of inspiration for the 1899 and 1907 Hague Peace Conferences. ${ }^{7}$ Until then, such studies had been undertaken by the Institut and other scientific societies only, but in the Final

2 Albéric Rolin, Les origines de l'Institut de Droit international 1873-1923 - Souvenirs d'un témoin par le Baron Albéric Rolin (Vromant 1923), 7-8.

3 Gustave Rolin-Jaequemyns, 'La nécessité d'organiser une Institution scientifique permanente pour favoriser l'étude et les progrès du Droit International' (1873) RDILC 463, 463-465.

4 See 'Conférence juridique internationale de Gand. Fondation de l'Institut de droit international' ibid 529; 'Communications et documents relatifs à l'Institut de droit international' ibid 667 .

5 IDI, 'Projet de règlement pour la procédure arbitrale internationale' (1877) 1 AnnIDI 126.

6 IDI, 'Les lois de la guerre sur terre. Manuel publié par l'Institut de droit international' (Oxford 1881-1882) 5 AnnIDI 157.

7 IDI, 'Séance solennelle d'ouverture de la session. Jeudi 6 septembre 1900 ( 2 h. après midi)' (Neuchâtel 1900) 18 AnnIDI 121, 138. 
Act of the 1907 Hague Conference it was proposed that governments should charge a committee to prepare the work, including determining the topics that would be fit for regulation, and to be discussed for the next Hague Conference, originally envisaged for $1914 .{ }^{8}$ It is interesting to note how this indicated a shift from individual scientific associations towards intergovernmental initiative for codification. However, the outbreak of the First World War prevented the convening of this third Hague Peace Conference scheduled for 1915. The war also led inevitably to a certain loss of faith in the strength of international law to maintain peace and observe the laws of war. ${ }^{9}$ In order to achieve the objectives set after the First World War - permanent status of peace, restoration of confidence amongst populations and the establishment of close cooperation between nations - three organisms were created by the Treaty of Versailles: the League of Nations, the Permanent Court of International Justice and the International Labour Organization. ${ }^{10}$ It was also decided to undertake the codification of international law (jus gentium) with the idea that this would foster the achievement of the aforementioned objectives. ${ }^{11}$

\section{Interaction between the Institut and the League of Nations}

This attempt to undertake codification took shape in the context of the preparations for the League of Nations Codification Conference, held in 1930. In 1924, the League of Nations adopted a resolution on the creation of a standing organ that would be charged, after possible consultation of the most authorized institutions dedicated to the study of international law, to draft a provisional

8 'Final Act of the Second Peace Conference' (The Hague 15 June - 18 October 1907), reproduced in Shabtai Rosenne, The Hague Peace Conferences of 1899 and 1907 and International Arbitration. Reports and Documents (T.M.C. Asser Press 2001) 412.

9 The Institut held an extraordinary session in Paris in 1919 "que le Bureau a jugé utile de tenir pour marquer comme l'a bien dit un de nos membres 'lintention de vivre'. C'est par cet acte de viabilité que répond l'Institut à quelques pessimistes - même quelques membres - qui avaient perdu leur foi dans l'avenir du droit international et dans la possibilité pour l'Institut de regalvaniser des doctrines dont la guerre avait plutôt montré l'inefficacité" 27 AnnIDI 295.

10 Treaty of Versailles, in particular the preamble, Part I, article 14 (PCIJ) and article 23(a) (ILO). Three ID I members were involved in the Paris Peace Conference as representatives of the following High Contracting Parties: the Cuban Republic represented by Antonio Sánchez de Bustamante, Greece (the Hellenes) by Nicolas Politis, and the Serbs, the Croats and the Slovenes by Milenko Vesnitch. IDI, 'Travaux préparatoires de la Session de New-York' (New York 1929) 35-I AnnIDI 3. 
list of topics of international law on which international agreement would seem the most desirable and achievable with a view to prepare a codification conference. ${ }^{12}$ The "Committee of Experts for the Progressive Codification of International Law" was composed of 17 members, 6 of them members of the Institut at the time of its creation, including the President of the Committee, Mr. Hammerskjöld, and the Vice-President, Mr. Diéna. ${ }^{13}$

The League of Nations reached out to the Institut in 1925, requesting advice on topics of international law for which international agreement would be possible, and communicated a list of subjects adopted by the League's Committee of Experts for the Institut to study. ${ }^{14}$ Following this, the Institut established a commission during its 1925 session in The Hague to study the topics adopted by the Committee of Experts and reported on it at the next session in $1927 .{ }^{15}$

After having received the views of States on the subject matters proposed to them, ${ }^{16}$ the Assembly of the League of Nations ultimately identified three questions of international law (nationality, territorial waters and responsibility of States) to be discussed at the Codification Conference of the League of Nations in The Hague in 1930. ${ }^{17}$

In the meantime, the Institut had adopted resolutions on all three subject matters before the Codification Conference: in 1927 on the responsibility of

12 League of Nations, 'Resolution adopted by the League of Nations Assembly on 22 September 1924' League of Nations Official Journal Spec Supp 21, 10.

13 Members of the Institut at the time of creation: Hjalmar Hammerskjöld (President), Giulio Diéna (Vice-President), Henri Fromageot, Bernhard C.J. Loder, Walter Schücking and Charles de Visscher; members of the Committee who became members of the Institut after its creation: James Brierly (1929), Gustavo Guerrero (1947) and Barboza de Magalhaes (1932); other members of the Committee: Christobal Botella, Adalbert Mastny, Michikazu Matsuda, Raymon Rundstein, José Léon Suarez, Wang-Chung-Hui and George W. Wickersham.

14 Joost A van Hamel, 'Lettres du Directeur de la Section juridique de la Société des Nations' (The Hague 1925) 32 AnnIDI 406.

15 IDI, 'Résolution IV' ibid 542, 542-543.

16 Subjects proposed were: nationality, territorial waters, diplomatic privileges and immunities, responsibility of states in respect to injury caused in their territory to persons or property of foreigners, procedure of international conferences and procedure for the conclusion and drafting of treaties, piracy, and the exploitation of the products of the sea.

17 See 'Report of the Council of the League of Nations' (13 June 1927) and 'Resolution adopted by Assembly of the League of Nations' (27 September 1927). It also provided for a preparatory committee composed of five persons, of which Professor Basdevant (France), Professor François (Netherlands) and Sir Cecil Hurst (Great Britain) were also members of the Institut. The other two members were Counsellor Carlos Castro Ruiz (Chile) and Mr. Massimo Pilotti (Italy). 
States ${ }^{18}$ and in 1928 on nationality and territorial waters. ${ }^{19}$ In 1928 it also created a commission for the codification of international peace law. ${ }^{20}$ Hence, the preparatory work for the Codification Conference was to a large extent inspired by the resolutions of the Institut.$^{21}$ Furthermore, the plenary of the Institut adopted unanimously a Codification Declaration in 1928 in which it spelled out some modalities for codification and also emphasized the pertinence of having the study of codification carried out by independent scientific organisations. Ninety years later this declaration still provides interesting reading. ${ }^{22}$

The League of Nations Codification Conference took place in 1930. However, for various reasons ${ }^{23}$ it proved not to be a great success; from the three subject matters that were put on the agenda only one, on nationality, led to the adoption of a treaty. ${ }^{24}$ No further codification efforts were made until after the Second World War.

18 IDI, 'Responsabilité internationale des Etats à raison des dommages causés sur leur territoire à la personne et aux biens des étrangers' (Lausanne 1927) 33-III AnnIDI 330.

19 See 'La nationalité' (Stockholm 1928) 34 AnnIDI 76o; and 'Projet de règlement relatif à la mer territoriale en temps de paix' ibid 755 .

20 Rapporteurs: Lord Phillimore and Mr. Alvarez. Members: Mr. Cavaglieri, Mr. Diéna, Sir Cecil Hurst, Mr. de Lapradelle, Mr. Mercier, Mr. Nippold, Mr. Schücking, Count de Itostworowski, Mr. De Visscher, Mr. Wehberg.

21 IDI, 'La Codification du Droit International de la Paix. Séance du mercredi 16 octobre 1929' (New York 1929) 35-II AnnIDI 272, 281-282. During the League of Nations Codification Conference, Basdevant was appointed Chairman of the committee on responsibility of States and another member of the Institut, Nicolas Politis, was appointed Chair of the committee on Nationality. Also, J.P.A. François was appointed Rapporteur on territorial waters.

22 IDI, 'Déclaration relative à la Codification du droit international' (New York 1929) 35-II AnnIDI 312. In the Declaration the Institut declared that: a) codification shall not be limited to stating the prevailing ius gentium as it is but shall also develop the law as it should be; b) codification can only be achieved if the determination of the rules is undertaken first of all by independent scientific organisms, grouping jurists of different nationalities, which allows for the adoption of resolutions by majority instead of by unanimity as the practice of diplomatic conferences; c) the study of codification has to be preceded by independent scientific preparation, which should be based on observation, jurisprudence and doctrine; and d) the determination of the rules shall be completed by taking into account all parts of the law, without being guided by political interest but by the legal maturity of such rules following the progress of the doctrine and jurisprudence and inspired by the general principles of law.

23 See for example Shabtai Rosenne, 'Codification Revisited After 5o Years' (1998) 2 MaxPlanckYrbkUNL 3.

24 Convention on certain questions relating to the conflict of nationality laws (adopted 12 April 1930, entered into force 1 July 1937) 4137 LNTS 89. Nevertheless, a resolution was adopted by the Assembly establishing a procedure for the future on codification, enabling States to propose subjects for codification for the consideration of the Assembly to decide 
The Institut reconvened for the first time after the Second World War in Lausanne in 1947, where it focused on the most fundamental and contemporary issues at that time, in particular fundamental human rights and the codification of public international law. The report by Rapporteur Alvarez (Chile) revolved around the methods of codification of public international law. ${ }^{25}$ The point of departure: on the one hand, the immense crisis that international law found itself in after the Second World War, and, on the other, the unanimous public opinion as also expressed in the Charter of the United Nations (Article 13) to return to international law its importance and prestige by progressively developing and codifying it. ${ }^{26}$ Rapporteur Alvarez explained that different views existed among public international lawyers on how to address the crisis: some underlined the importance of reaffirming the principles of international law still in force (the Anglo-Saxon approach); others considered that the only means to render prestige to international law was to proceed rapidly to its codification.

In its 1947 resolution on codification, the Institut underlined the dangers of the method used in 1930 for the League of Nations Codification Conference, to the extent that the binding force of the rules codified depended on the express acceptance of States. This carried the risk that each government had the possibility to question it, or even to refuse to accept rules of law that the doctrine and jurisprudence considered as established. The resolution indicated that such an approach could likely result in the weakening of the rules which were meant to be detailed and consolidated through codification. Emphasis was therefore placed on the research of a scientific character to discover the current state of international law, which could then serve as a basis for both doctrinal and official efforts to fill the gaps in international law. ${ }^{27}$

In the proceedings one can nicely read how theory and practice can sometimes meet each other in our Institut. ${ }^{28}$ During the deliberations, one of the members of the Institut, Mr. Donnedieu de Vabres from France, took the floor.

whether the subjects proposed appear at first glance suitable for codification. League of Nations, 'Resolution adopted by the Assembly of the League of Nations, 25 September 1931' League of Nations Official Journal Spec Supp 92, 9.

25 Alejandro Alvarez, 'Méthodes de la codification du droit international public' (Lausanne 1947) 41 AnnIDI 38.

26 Ibid 40.

27 IDI, 'La Codification du Droit international' (Lausanne 1947) ibid 261.

28 See 41 AnnIDI (Lausanne 1947) 38-71 (for the preparatory work) and 218-254 (for the deliberations). 
He was also member of the Committee on the Progressive Development of International Law and its Codification, also known as the "Committee of Seventeen", established by the United Nations General Assembly to make recommendations for the setting up of the International Law Commission. Mr. Donnedieu de Vabres explained to the members of the Institut what the United Nations Committee was considering in its report. ${ }^{29}$

He stated that what the Rapporteur, Mr. Alvarez, proposed, namely first having the scientific societies preparing a draft before submitting it to States, would risk divergence between the universal conscience and the harsh international reality. This could well create a danger of not reaching any agreement at all. This is why the Committee insisted on a constant collaboration of all interested parties, including governments, in order to achieve conciliation of theory and practice. Furthermore, he informed the Institut of the discussions on the distinction between codification and progressive development of international law. He also explained the procedure foreseen and elaborated on the question of the form of the drafts: doctrinal or draft conventions. The influence of government representatives led the Committee to decide on a modality of conventions, either between two States or between multiple States.

The idea was that such an international law commission could be seized by the General Assembly, but also by other organs of the United Nations. The specialized agencies of the United Nations could also submit proposals and draft multilateral conventions.

The General Assembly, following the report of the Committee, adopted a resolution establishing the International Law Commission and approved its statute, ${ }^{30}$ in which indeed a considerable role is given to States while also providing for the possibility of consultation with scientific institutions and individual experts. ${ }^{31}$ The International Law Commission held its first session in 1949 and of the 15 members of the Commission at the first session, 10 also were, or subsequently became, members of the Institut. ${ }^{32}$

29 Ibid 224-227.

30 Statute of the ILC, UNGA Res 174 (II) (21 November 1947), subsequently amended by Unga Res 485(v) (12 December 1950); Unga Res 984(x) (3 December 1955); UngA Res 985 (x) (3 December 1955) and unga Res 36/39 (18 November 1981).

31 See article $26(1)$ of the ILC statute $\left(\mathrm{n}_{31}\right)$.

32 Mr. Ricardo J. Alfaro (Panama, 1954); Mr. James Leslie Brierly (United Kingdom, 1929); Mr. J.P.A. François (Netherlands, 1937); Mr. Manley O. Hudson (United States of America, 1936); Mr. Vladimir M. Koretsky (Union of Soviet Socialist Republics, 1965); Mr. A.E.F. Sandström (Sweden, 1950); Mr. Georges Scelle (France, 1929); Mr. Jean Spiropoulos (Greece, 1950); Mr. Jesús M. Yepes (Colombia, 1952); Mr. Jaroslav Zourek (Czechoslovakia, 1961). The year indicates the year of election to the Institut. 
Having both our institutions working toward a common goal, it is interesting to take a look at their similarities and differences, to better understand how this shared objective is achieved. Both institutions promote the progressive development of international law and its codification. The Institut, in its statutes, outlines six ways in which it aims to achieve this, namely: a) formulating general principles; b) working on gradual and progressive codification of international law; c) seeking official endorsement of the principles; d) contributing to the maintenance of peace, or to the observance of the laws of war; e) studying the difficulties in the interpretation or application of the law; and $f$ ) facilitating co-operation in the teaching and dissemination of international law. ${ }^{33}$

The statute of the International Law Commission states that "the International Law Commission shall have for its object the promotion of progressive development of international law and its codification". The two concepts are succinctly described in article 15: progressive development is to be understood as the preparation of draft conventions on subjects which have not yet been regulated by international law or in which law has not yet been sufficiently developed in the practice of States, while codification means the more precise formulation and systematization of rules of international law in fields where there has already been extensive State practice, precedent and doctrine.

As regards the scope of the work, the Commission "shall concern itself primarily with public international law, but is not precluded from entering the field of private international law", which differs from the scope of the work of the Institut in that it covers both fields of international law (public and private) equally. ${ }^{34}$

33 In a full quote: "a) by striving to formulate the general principles of the subject, in such a way as to correspond to the legal conscience of the civilized world; b) by lending its co-operation in any serious endeavour for the gradual and progressive codification of international law; c) by seeking official endorsement of the principles recognized as in harmony with the needs of modern societies; d) by contributing, within the limits of its competence, either to the maintenance of peace, or to the observance of the laws of war; e) by studying the difficulties which may arise in the interpretation or application of the law, and where necessary issuing reasoned legal opinions in doubtful or controversial cases; f) by affording its co-operation, through publications, public teaching and all other means, in ensuring that those principles of justice and humanity which should govern the mutual relations of peoples shall prevail." See 'Statutes of the Institute of International Law' (adopted 10 September 1873, English translation) <www.idi-iil.org/app/uploads/ 2017/o6/Statutes-of-the-Institute-of-International-Law.pdf >.

Article 1(2) of the ILC statute; Article 9(5) of the IDI rules. 
As already mentioned, the Institut is an exclusively learned society without any official nature. The total number of members under the age of 80 shall not exceed 132 and there can be more than one national from the same State. ${ }^{35}$ In fact, in case of three or more members of the same nationality, national groups can be formed. ${ }^{36}$ Currently, we have 21 of such national groups. The plenary assembly elects associate members from a list of candidates proposed by the national groups and the Bureau. After having attended three sessions of the Institut, associate members qualify to become full members. In principle, membership can be for life.

In contrast, the International Law Commission is a subsidiary organ of the United Nations General Assembly, reporting to the plenary meeting of States and hence with a close link to its Sixth Committee, as we will discuss this afternoon. Over the years, the membership of the International Law Commission has increased to a total number of 34 and there cannot be two members with the nationality of the same State. ${ }^{37}$ Members are elected by the General Assembly from a list of candidates nominated by States. ${ }^{38}$ They are elected for a period of five years with possibility of re-election. Even though the statute of the Commission does not explicitly bar it, ${ }^{39}$ no judges of the International Court of Justice are simultaneously members of the International Law Commission, while currently out of the 15 judges 8 are a member of the Institut. ${ }^{40}$

Members of the International Law Commission can be members of the Institut at the same time. In fact, from the 229 persons that have been members of the Commission, 83 have been or are members of the Institut, either concurrently or at an earlier or later point in time. ${ }^{41}$ Thirty-seven of them have served as Special Rapporteur for the Commission and 16 of them as Rapporteur of a commission

35 Article 3 of the IDI statute.

36 Article 9 of the IDI rules.

37 Article 2 of the ILC statute.

38 Article 3 of the ILC statute.

39 Article 10 of the ILC statute.

40 Mr Yusuf (President), Mrs Xue (Vice-President), Messrs Tomka (former President), Bennouna, Cançado Trindade, Crawford, Gaja, Owada (succeeded by Mr Iwasawa on 22 June 2018 who is also a member of the Institut).

41 Roberto Ago, Ricardo J. Alfaro, Gaetano Arangio-Ruiz, Milan Bartoš, Mohamed Bedjaoui, Mohamed Bennouna, Boutros Boutros-Ghali, Derek William Bowett, James Leslie Brierly, Herbert W. Briggs, Sir Ian Brownlie, Lucius Caflisch, Jorge Castañeda, Erik Castrén, James Richard Crawford, C. John R. Dugard, Abdullah El-Erian, Taslim Olawale Elias, Nihat Erim, Constantin Th. Eustathiades, Jens Evensen, Luigi Ferrari Bravo, Sir Gerald Fitzmaurice, J.P.A. François, Giorgio Gaja, André Gros, Gerhard Hafner, Edvard Hambro, Manley O. Hudson, Eduardo Jimenez de Arechaga, Maurice Kamto, James Lutabanzibwa Kateka, Roman Anatolyevich Kolodkin, Vladimir M. Koretsky, Abdul G. Koroma, Martti 
of the Institut. Both institutions aim for a representation of the principal legal systems and the candidates should have the necessary qualifications. We have a number of fantastic female members. Unfortunately, women are still underrepresented in both bodies.

Neither the International Law Commission nor the Institut is a full-time body. The Institut has one session every two years of some seven days, whereas the Commission convenes on an annual basis for 11 to 12 weeks. The methods of work of the Institut are fairly settled and quite similar to those of the International Law Commission. Commissions are led by a Rapporteur and work on a subject of international law that has been put on the agenda by the Plenary, on proposal of the Programme Committee. ${ }^{42}$ The Plenary Assembly examines their reports and draft resolutions and, if appropriate, resolutions of a normative character are adopted. ${ }^{43}$ Through these resolutions, the Institut seeks to highlight the characteristics of the prevailing law, lex lata, in order to promote respect and full observance. Furthermore, the Institut makes de lege ferenda determinations in order to contribute to the development of international law. However, in contrast with the method of the International Law Commission, ${ }^{44}$ no consultation rounds with States or other bodies are held, although governments and international organisations are informed of the resolutions adopted by the Institut. The International Law Commission, when adopting a draft, submits it to the General Assembly with its recommendations. The General Assembly then decides what kind of action to take.

It is interesting and rewarding to note that the work of the Institut and the work by the International Law Commission over the last 70 years have informed, developed and reinforced each other on many occasions. When taking a look at the subject matters dealt with by the International Law Commission, many of them are, or have also been dealt with, by the Institut: in their entirety or partially, and

Koskenniemi, Sergei B. Krylov, Manfred Lachs, Sir Hersch Lauterpacht, Antonio de Luna, Ahmed Mahiou, Donald M. McRae, Václav Mikulka, Djamchid Momtaz, Shinya Murase, Zhengyu Ni, Georg Nolte, Alain Pellet, A. Rohan Perera, Christopher Walter Pinto, Pemmaraju Sreenivasa Rao, August Reinisch, Paul Reuter, Shabtai Rosenne, Emmanuel J. Roucounas, José María Ruda, Milan Sahovic, A.E.F. Sandström, Georges Scelle, Stephen M. Schwebel, Bernardo Sepúlveda, César Sepúlveda-Gutiérrez, José Sette Câmara, Bruno Simma, Sir Ian Sinclair, Nagendra Singh, Jean Spiropoulos, Sompong Sucharitkul, Dire D. Tladi, Peter Tomka, Christian Tomuschat, Grigory I. Tunkin, Endre Ustor, Sir Francis Vallat, Alfred Verdross, Stephen Verosta, Sir Humphrey Waldock, Xue Hanqin, Alexander Yankov, Mustafa Kamil Yasseen, Jesús María Yepes, Kisaburo Yokota, Jaroslav Zourek.

42 Chapter I, IDI rules.

43 Chapter III, Part Three, IDI rules.

44 Articles $16-26$ of the ILC statute. 
previously, concurrently or at a later stage. Reference can be made to such diverse topics as diplomatic immunities, diplomatic protection, State responsibility, extradition, the law of treaties, expulsion of aliens, the most-favoured nation clause, and arbitral procedure. In drawing a balance, I believe it is no exaggeration to state that the progressive development and codification of international law until today can to some extent be measured by the work of our two institutions.

\section{Some Examples of Common Efforts at International Law-Making}

Let me now proceed to providing some examples of common efforts in international law-making. An early example, starting late nineteenth century, relates to the subject-matter nationality including statelessness. The Institut has adopted several resolutions ${ }^{45}$ and the International Law Commission considered it during the early $195{ }^{\circ},{ }^{46}$ leading to the adoption of the United Nations Convention on the Reduction of Statelessness in 1961, with currently 71 parties. ${ }^{47} \mathrm{~A}$ second example is the non-navigational use of international watercourses on which the Institut adopted a resolution as early as $1911,{ }^{48}$ another one in $1961^{49}$ and more specifically one on the pollution of watercourses in $1979 .{ }^{50}$ The International Law Commission took up the topic in 1971 in its programme of work, ${ }^{51}$ leading to the adoption of the Convention

451892 Geneva (admission et expulsion des étrangers), 1896 Venice (nationalité), 1928 Stockholm (nationalité), 1929 New York (droits de l'homme), 1932 Oslo (capacité des personnes (amendant la loi applicable à la capacité des apatrides mineurs, aliénés)), 1936 Brussels (Statut juridique des apatrides et des réfugiés), 1950 Bath (L'asile en droit international public (à l'exclusion de l'asile neutre)) <http://www.idi-iil.org/en/publicationspar-categorie/resolutions/>.

46 See 'Analytical Guide to the Work of the International Law Commission: Nationality including statelessness' <http://legal.un.org/ilc/guide/6_1.shtml>.

47 Adopted 30 August 1961, entered into force 13 December 1975, 989 UnTs 175.

48 IDI, 'Texte des Résolutions adoptées en ce qui concerne la Règlementation internationale de l'usage des cours d'eau internationaux.' (Madrid 1911) 24 AnnIDI 365.

49 IDI, 'Utilisation des eaux internationales non maritimes (en dehors de la navigation)' (Salzburg 1961) 49-II AnnIDI 370.

50 1911 Madrid (Réglementation internationale de l'usage des cours d'eau internationaux en dehors de l'exercice du droit de navigation), 1961 Salzbourg (Utilisation des eaux internationales non maritimes (en dehors de la navigation)), 1979 Athens (La pollution des fleuves et des lacs et le droit international) <http://www.idi-iil.org/en/publications-parcategorie/resolutions/>.

51 See 'Analytical Guide to the Work of the International Law Commission, Law of the non-navigational uses of international watercourses' $<$ http://legal.un.org/ilc/guide/8_ 3.shtml>. 
on the Law of the Non-navigational Uses of International Watercourses in 1997, currently counting 36 parties. ${ }^{52}$ A final early example relates to the regime of the territorial sea, more in particular the issue of the breadth of the territorial sea. In its first resolution on the territorial sea in $1894,{ }^{53}$ the Institut endorsed the "cannon-shot rule" coined by the Dutch lawyer Van Bijnkershoek (I come from the same West Frisian region), that is a territorial sea corresponding to the range of the coastal State's defence weapons on our dikes, so to say. ${ }^{54}$ In view of the tendency in State practice to extend the territorial sea beyond the three nautical miles for purposes of protecting their coastal fishery interests, the Institut made an attempt to align theory and practice by proposing a six nautical miles limit. This discussion was still ongoing when, in 1928, the Institut adopted another resolution proposing a draft regulation concerning the territorial sea in times of peace, but even its two rapporteurs had a difference of opinion on whether it should be three or six nautical miles..$^{55}$ In the end, the three-nautical miles limit was adopted, as well as an article on the additional contiguous zone not exceeding nine nautical miles. As discussed, the 1930 Codification Conference of the League also proved to be deeply divided on this and failed to take a decision. In the 195os, the topic of the breadth of the territorial sea was revisited, both in the International Law Commission and the Institut. However, both institutions left the actual breadth of the territorial sea open, only indicating that it could not extend beyond 12 nautical miles. ${ }^{56}$ It was only in the context of the Third United Nations Conference on the Law of the Sea that the international community of States settled, in 1982, for a territorial sea of 12 nautical miles. ${ }^{57}$

$52 \quad$ Adopted 21 May 1997, entered into force 17 August 2014, UNTS registration no 52106.

53 IDI, 'Règles adoptées par l'Institut de droit international, à Paris, le 31 mars 1894, sur la définition et le régime de la mer territoriale' (Paris 1894-1895) 13 AnnIDI 328.

54 Cornelis Van Bijnkershoek, De dominio maris (Leiden, 1703) (and see also second edition of Opera minora in 1744); 1894 Paris (Règles sur la définition et le régime de la mer territoriale) <http://www.idi-iil.org/fr/publications-par-categorie/resolutions/>.

IDI, 'Règlement sur le régime des navires de mer et de leurs équipages dans les ports étrangers en temps de paix' (Stockholm 1928) 34 AnnIDI 736.

56 See e.g. Amsterdam (1957) 47-II AnnIDI 169; [1952] II ILC Ybk UN Doc, A/CN.4/53, 26; [1953] II ILC Ybk UN Doc, A/CN.4/61, 59-65; and [1956] II ILC Ybk UN Doc, A/CN.4/104, 256, article 3. At both places the Dutchman J.P.A. François played a leading role, respectively as Special Rapporteur for the International Law Commission and as President during the Amsterdam Session of the Institut.

57 United Nations Convention on the Law of the Sea, adopted 10 December 1982, entered into force 16 November 1994, 1833 UNTS 3, article 3. 
Probably the most well-known and most successful topic taken up by the International Law Commission so far is the law of treaties. This was prioritized during its first session in 1949 and led to the adoption of the Vienna Convention on the Law of Treaties 20 years later, ${ }^{58}$ with full participation of developing countries as also demonstrated by the recognition of the concept of jus cogens ${ }^{59}$ and the clause on the fundamental change of circumstances. ${ }^{60}$ Currently, the treaty has 116 parties. ${ }^{61}$ Equally important, if not more important, is that most of its provisions are found to reflect, in the view of the International Court of Justice, ${ }^{62}$ prevailing customary international law. In my view, this Convention is the real beauty, the crown jewel of the International Law Commission. Let me briefly mention that the Institut also discussed the issue of interpretation of treaties earlier, in 1956, on the basis of the work of a commission led by Sir Hersch Lauterpacht, who also served as the International Law Commission's Special Rapporteur on the law of treaties in the early 1950 os. ${ }^{63}$ Furthermore, the topic of termination of treaties has always faced some challenges and remains regrettably topical in these days of Brexit, clexit (climate exit) and the withdrawal by the United States of America from the so-called "Iran deal" 64 and the Intermediate-Range Nuclear Forces (INF) treaty. ${ }^{65}$ Termination of treaties was addressed by the Institut in its resolution of 1967 , in which it recognized the value of the work accomplished by the International Law Commission and addressed certain aspects of the general problem of the termination of treaties. ${ }^{6}$

A topic that was excluded from the scope of the Vienna Convention was the effect of armed conflicts on treaties. ${ }^{67}$ Following the 1907 Hague Conference,

$5^{8}$ Adopted 23 May 1969, entered into force 17 January 1980, 1155 UNTS 331 (VCLT).

59 Article 53 of the VCLT.

6o Article 62 of the vCLT.

61 See for a recent contribution on treaties Georg Nolte, Treaties and their Practice. Symptoms of Their Rise or Decline (Brill/Pocket Books of The Hague Academy of International Law 2018).

62 See e.g. Legal Consequences for States of the Continued Presence of South Africa in Namibia (South West Africa) notwithstanding Security Council Resolution 276 (1970) (Advisory Opinion) [1971] ICJ Rep 47.

63 IDI, 'L'interprétation des traités' (Grenade 1956) 46 AnnIDI 358.

64 Joint Comprehensive Plan of Action (JCPOA), concluded 14 July 2015, adopted as part of UNSC Res 2231 (20 July 2015).

65 Treaty Between the United States of America and the Union of Soviet Socialist Republics on the Elimination if Their Intermediate-Range and Shorter-Range Missiles (INF Treaty), signed 8 December 1987, entered into force 1 June 1988, 1657 UNTS 2.

66 IDI, 'La terminaison des traité' (Nice 1967) 52-II AnnIDI 556.

67 ILC, 'Report of the International Law Commission on the work of its fifteenth session' [1963] II ILC Ybk 188, 189 at para 14. 
the Institut adopted a resolution in 1912 on the effects of war on treaties. ${ }^{68}$ The abolition theory, i.e. that war ended all relations between belligerents, was rejected in the resolution. As a rule, the outbreak of hostilities would have no effects on the existence of treaties, with the exception, inter alia, of treaties of a political nature and treaties of which the interpretation or application was the direct cause of the war. Similarly, multilateral treaties would in principle remain intact, but collective treaties on the law of war would apply only when all belligerents were contracting states (unless the treaty contained a formal clause to the contrary or the parties clearly intended for it to apply). ${ }^{69}$

Following the adoption of the Vienna Convention, which explicitly excluded in article 73 the effects of war on treaties from its scope, the Institut created a commission in 1973 to re-examine the matter. After extensive deliberations, it adopted in 1985 a resolution on the effects of armed conflicts on treaty regimes. ${ }^{70}$ Subsequently, the International Law Commission put it on the agenda in 2004, pointing out that whereas the law remained, to a considerable degree, unsettled, the subject seemed now ready for codification and/or progressive development. ${ }^{71}$ Inspired in part by the resolution adopted by the Institut and new developments in international law, including with respect to intra-State conflicts or non-international armed conflicts, ${ }^{72}$ the International Law Commission drafted a set of substantive articles on the matter and adopted these in $2011{ }^{73} \mathrm{~A}$ final and very recent example of our interactions relates to the work

68 IDI, 'Règlement concernant les effets de la guerre sur les traités' (Christiania 1912) 25 AnnIDI 648.

69 Unless a formal clause to the contrary or clear intention by parties. (Christiania 1912) 25 AnnIDI 611ff. It was acknowledged that the work of the Institut in 1912 had a relatively strong influence on the cases that were decided during the First World War and immediately thereafter, including by the courts of various countries. See Bengt Broms 'The effects of armed conflicts on treaties. Provisional Report and Proposed Draft Resolution' (Dijon 1981) 59-I AnnIDI 201, 213.

70 IDI, 'The effects of armed conflicts on treaties / Les effets des conflits armés sur les traités' (Helsinki 1985) 61-II AnnIDI 278.

71 ILC, 'Report of the International Law Commission on the work of its fifty-second session' [2000] II (2) ILC Ybk 1, 131 at para 729.

72 The International Law Commission uses a definition of "armed conflict" that is mainly based on the definition as set out in the Tadic Case [Prosecutorv Dusko Tadic a/k/a "Dule" (Decision on the Defence Motion of Interlocutory Appeal on Jurisdiction) ICTY-94-1 (15 July 1999)] which includes non-international armed conflicts (excluding the situation in which only two or more organized armed groups are involved), see ILC, 'Draft articles on the effects of armed conflicts on treaties, with commentaries' [2011] II(2) ILC Ybk 108, 110, commentary to draft article 2 para (4) at footnote 401.

73 ILC, 'Report of the International Law Commission on the work of its sixty- third session' [2011] II(2) ILC Ybk, Chapter VI. On 7 December 2017, the General Assembly decided that 
of our Secretary-General Marcelo Kohen on the question of State succession in matters of State responsibility. Based upon his extensive report, the Institut adopted a resolution on this in $2015^{74}$ and the topic has now been included by the International Law Commission in its programme of work in $2017,{ }^{75}$ to be discussed at the current session. ${ }^{76}$

\section{The Future: Is Standard-Setting in International Law Completed or is There Still an International Law Agenda for the Future? What Roles for the Commission and the Institut?}

This leads us to consider where we stand at the moment and what the future will bring for the development of international law and its codification. Could it be said that standard-setting in international law has been completed? Or is there still work to be done? If so, what are the respective roles of the Commission and the Institut? As mentioned in the beginning of my contribution, the Institut was created shortly after the Franco-German War out of a deeply felt desire to address the need for the progressive development of international law as a means to bring peace, or at least to render war an exception. It was for that mission and for the quality of its work in the initial decades that the Institut was granted the Nobel Peace Prize in 1904.

After every war, the importance of progressive development of international law and its codification has been reaffirmed, even though the effectiveness of international law to prevent or reduce the horrors of war has sometimes been severely questioned. Similar sentiments led to the establishment of the International Law Commission after the Second World War. If we look at the situation today, it is appropriate to recall the opening remarks at a press conference last week by the United Nations Secretary-General. Mr. Guterres referred to contemporary dangers and challenges including the threat of terrorism, the multiplication of armed conflicts, climate change, and dramatically increased inequalities, to which we can easily add the refugee crisis and the issue of migration and human security, a topic on which our Institut adopted

it would revert to the question of the effects of armed conflicts on treaties at an appropriate time. UNGA Res 72/121 (7 December 2017).

74 IDI, 'La succession d'Etats en matière de responsabilité internationale' (Tallinn 2015) 76 AnnIDI 703 .

75 ILC, 'Report of the International Law Commission on the work at its sixty-ninth session' (2017) UN Doc A/72/10, para 263.

76 ILC, 'Provisional agenda for the seventieth session' (13 April 2018) UN Doc A/CN.4/709/ Rev.1. 
a substantive report and resolution in $2017 .{ }^{77}$ The Secretary-General rightly stressed that "in this dangerous world, it is absolutely essential to preserve [...] the rule of law in international relations." ${ }^{78}$

I do not subscribe to those academic colleagues who portray international law merely as a "belief". ${ }^{79}$ Rather, I view contemporary international law as the embodiment of shared global values such as peace, justice, humanity, freedom and sustainability. In our deeply divided world it is our common language. That is something to cherish. Moreover, international law also functions as a concrete regulatory framework for concrete action. And we need more of that function, as the recent Paris Agreement on the curbing of climate change demonstrates. ${ }^{80}$

It took a long period of gestation to arrive at the body of international law that we currently have. We know all too well that it is still fragile and in need of constant maintenance, if not reform, in order to remain relevant as the rule of law in global affairs. The International Law Commission has made a magnificent contribution to this, especially through the progressive development of international law and its consolidation through extensive and effective codification in the United Nations era. ${ }^{81}$ Its task is certainly not yet completed, nor is ours. It is my pleasure and great privilege to wish our younger sister institution a great future, in the interest of all of us.

77 IDI, 'Mass Migrations' (9 September 2017) <www.idi-iil.org/app/uploads/2017/o8/ 16-RES-FINAL-EN.pdf>.

78 Antonio Guterres, 'Opening remarks at joint press conference with European Commission President, Jean-Claude Juncker' (16 May 2018) < www.un.org/sg/en/content/sg/speeches/ 2018-05-16/remarks-press-conference-jean-claude-juncker>.

79 Cf. Jean D'Aspremont, International Law as a Belief System (CUP 2017).

8o Adopted 12 December 2015, entered into force 4 November 2016, UnTs registration no 54113 .

81 See for an evaluation of the work of the Commission Arthur Watts, 'Codification and Progressive Development of International Law' in Rüdiger Wolfrum (ed), The Max Planck Encyclopedia of Public International Law (Ou P 2012), vol II, 282-296; Pemmaraju Sreenivasa Rao, 'The International Law Commission' in Rüdiger Wolfrum (ed), ibid, vol v (2012), 875-888; Rosalyn Higgins et al., Oppenheim's International Law. United Nations (OUP 2017), vol II, 929-946. 
The United Nations - 9789004434271

Downloaded from Brill.com04/26/2023 02:31:42PM via free access 